\title{
Порівняльна характеристика ехогенної структури післяопераційних нормотрофічних та атрофічних рубців шкіри
}

\author{
Д. С. Аветіков ${ }^{1}$, О. П. Буханченко ${ }^{1}$ К. П. Локес ${ }^{1}$, І. В. Яценко ${ }^{1}$, Т. П. Локес-Крупка² \\ 'українська медична стоматологічна академія, м. Полтава, \\ ${ }^{2}$ Полтавська державна аграрна академія

\section{Comparative characteristics of echogenous structure of postoperative normotrophic and atrophic cutaneous cicatrices}

\author{
D. S. Avetikov'1, O. P. Bukhanchenko ${ }^{1}$, K. P. Lokes ${ }^{1}$, I. V. Yatsenko', T. P. Lokes-Krupka ${ }^{2}$ \\ ${ }^{1}$ Ukrainian Medical Stomatological Academy, Poltava, \\ 2Poltava State Agrarian Academy
}

\begin{abstract}
Peферат
Мета. Вивчити можливості диференціальної діагностики нормотрофічних і атрофічних післяопераційних рубців (ПОР) з використанням ультразвукового дослідження (УЗД).

Матеріали і методи. Обстежено 50 паціентів з рубцями голови та шиі. Ехогенні відмінності патологічних рубців встановлювали за допомогою УЗД.

Результати. Ехокартина атрофічних рубців характеризувалась меншою глибиною залягання рубцевої тканини, ніж товщина інтактної шкіри (мінімальне значення - 0,92 мм, максимальне - 2,14 мм). Власна зона рубця мала середній ступінь ехогенності з досить рівномірним розподілом волокон сполучної тканини.

Висновки. Застосування УЗД дає можливість визначити належність патологічного рубця до певного типу, що спрощує складання алгоритму лікування ПОР шкіри.

Ключові слова: нормотрофічний рубець; атрофічний рубець; ультразвукове дослідження; ехогенність.

Abstract

Objective. To study the possibilities of differential diagnosis of normotrophic and atrophic postoperative cicatrices, using ultrasonographic investigation.

Materials and methods. There were examined 50 patients, suffering craniocervical cicatrices. Echogenic peculiarities of pathological cicatrices were determined, using ultrasonographic investigation.

Results. Echopicture of atrophic cicatrices was characterized by lesser depth of the cicatricial tissue bedding, than the intact skin thickness (minimal value $-0.92 \mathrm{~mm}$, and maximal $-2.14 \mathrm{~mm}$ ). Immediate zone of cicatrix have had middle degree of echogenicity with quite plain distribution of the connective tissues fibers.

Conclusion. Application of ultrasonographic investigation makes possible to establish the pathological cicatrix type present to simplify the algorithm constructing for the postoperative cutaneous cicatrices treatment.

Keywords: normotrophic cicatrix; atrophic cicatrix; ultrasound investigation; echogenicity.
\end{abstract}

Діагностика ПОР шкіри була і залишається одним з актуальних питань сучасної щелепно-лицевої та пластичної хірургії [1]. Незважаючи на величезну кількість наукових робіт, присвячених вивченню етіології, патогенезу та лікуванню ПОР шкіри, їх диференціальній діагностиці досі приділяють недостатню увагу [2].

Досить часто для встановлення діагнозу та призначення адекватного лікування потрібно застосовувати додаткові методи дослідження: рентгенографію, опромінення ультрафіолетовими променями, капіляроскопію, гістологічне дослідження рубців шкіри [3, 4]. Однак використання даних методів для вивчення патологічних рубців обмежене через їх недостатню інформативність або складність проведення $[5,6]$. Тому обгрунтування та розробка ефективного алгоритму комплексного обстеження пацієнтів із патологічними рубцями з метою їх диференціальної діагностики та подальшого вибору оптимального лікування є актуальними не лише з медичної, а й із соціальної точки зору [7].

Мета дослідження: вивчити можливості диференціальної діагностики нормотрофічних і атрофічних ПОР з використанням УЗД.

\section{Матеріали і методи дослідження}

УЗД використали в обстеженні 50 пацієнтів із нормотрофічними та атрофічними рубцями голови та шиї. На наступному етапі дослідження відібрали пацієнтів 3 оптично візуалізованими нормотрофічними рубцями, будова яких була підтверджена морфологічно. У цю групу ввійшли пацієнти з рубцями, які мали гладкий рельєф і блідий колір, тканини не виступали над поверхнею шкіри. Ці пацієнти не скаржилися на больові відчуття, свербіж, знижену чи підвищену чутливість. Рубці у пацієнтів порівнювали з інтактною шкірою 50 здорових людей. 


\section{Результати}

3 метою математичного обгрунтування та встановлення кількісних показників ступеня ехогенності зон рубців обрали такі точки: Т1 - ділянка інтактної шкіри навколо рубця; Т2 - ділянка медіального краю рубця; Т3 - ділянка латерального краю рубця; T4 - середня зона рубця; L1 - межа між епідермісом та рубцевозміненою тканиною; L2 - межа між рубцевозміненою тканиною та гіподермою; L3 - межа між медіальним краєм рубця та інтактною дермою; L4 межа між латеральним краєм рубця та інтактною дермою.

Для об'єктивізації отриманих даних ввели два коефіцієнти: L1/2 - індекс, який показує характер зміни показників ехогенності в центральних та периферичних тканинах рубця в його середній зоні; L3/4 - індекс, який показує характер зміни показників ехогенності в медіальному та дистальному краях рубця.
Дані щодо показників ехогенності нормотрофічних рубців наведені в табл. 1

Вивчення показників ехогенності в зоні межі між епідермісом та рубцевозміненою дермою засвідчило, що вони були достовірно нижчі, середнє значення дорівнювало 63,9 (у жінок - 69,1, у чоловіків - 57,8).

Найбільшими були показники ехогенності в точці L2 на межі між рубцевозміненою тканиною та гіподермою. Середнє значення дорівнювало 96,5 (у жінок - 101,8, у чоловіків - 91,6)

Вивчивши показники ехогенності в точках L3 та L4, ми отримали достовірно схожі дані щодо однорідної гомогенної структури, яку підтверджували як якісні візуалізовані дані, так і кількісні: в точці L3 середній показник становив 69,3 (у жінок - 74,8, у чоловіків - 64,2), в точці L4 69,7 (75,2 та 64,7 відповідно).

\section{Таблиця 1. Розподіл кількісних показників ехогенності нормотрофічних рубців при УЗД}

\begin{tabular}{|c|c|c|c|c|c|c|c|c|c|c|}
\hline \multirow{2}{*}{ Спостереження } & \multicolumn{8}{|c|}{ Точки } & \multicolumn{2}{|c|}{ Коефіцієнти } \\
\hline & T1 & $\mathrm{T} 2$ & T3 & T4 & L1 & L2 & L3 & L4 & $\mathrm{L} 1 / 2$ & $\mathrm{~L} 3 / 4$ \\
\hline 1 & 71,0 & 61,0 & 58,0 & 56,0 & 58,0 & 101,0 & 66,0 & 65,0 & 0,57 & 1,02 \\
\hline 2 & 64,0 & 59,0 & 58,0 & 55,0 & 57,0 & 97,0 & 61,0 & 60,0 & 0,59 & 1,01 \\
\hline 3 & 82,0 & 74,0 & 76,0 & 71,0 & 74,0 & 109,0 & 78,0 & 79,0 & 0,68 & 0,99 \\
\hline 4 & 53,0 & 52,0 & 51,0 & 49,0 & 51,0 & 88,0 & 52,0 & 51,0 & 0,88 & 1,02 \\
\hline 5 & 76,0 & 75,0 & 73,0 & 71,0 & 72,0 & 96,0 & 76,0 & 78,0 & 0,75 & 0,97 \\
\hline 6 & 69,0 & 62,0 & 65,0 & 58,0 & 64,0 & 94,0 & 65,0 & 67,0 & 0,68 & 0,97 \\
\hline 7 & 62,0 & 57,0 & 59,0 & 54,0 & 55,0 & 91,0 & 60,0 & 61,0 & 0,60 & 0,98 \\
\hline 8 & 83,0 & 74,0 & 77,0 & 72,0 & 74,0 & 106,0 & 79,0 & 81,0 & 0,70 & 0,96 \\
\hline 9 & 87,0 & 81,0 & 79,0 & 74,0 & 75,0 & 109,0 & 84,0 & 83,0 & 0,69 & 1,01 \\
\hline 10 & 79,0 & 63,0 & 66,0 & 61,0 & 63,0 & 93,0 & 68,0 & 70,0 & 0,68 & 0,97 \\
\hline 11 & 73,0 & 64,0 & 59,0 & 53,0 & 56,0 & 88,0 & 69,0 & 67,0 & 0,64 & 1,03 \\
\hline 12 & 81,0 & 74,0 & 75,0 & 71,0 & 75,0 & 95,0 & 77,0 & 78,0 & 0,79 & 0,99 \\
\hline 13 & 59,0 & 55,0 & 52,0 & 48,0 & 51,0 & 82,0 & 57,0 & 57,0 & 0,62 & 1,00 \\
\hline 14 & 64,0 & 58,0 & 57,0 & 52,0 & 52,0 & 86,0 & 61,0 & 61,0 & 0,60 & 1,00 \\
\hline 15 & 89,0 & 83,0 & 85,0 & 77,0 & 81,0 & 112,0 & 86,0 & 87,0 & 0,72 & 0,99 \\
\hline Середнє значення & 72,8 & 65,8 & 66,0 & 61,5 & 63,9 & 96,5 & 69,3 & 69,7 & 0,68 & 1,39 \\
\hline
\end{tabular}

\section{Таблиця 2. Розподіл кількісних показників ехогенності атрофічних рубців при УзД}

\begin{tabular}{|c|c|c|c|c|c|c|c|c|c|c|}
\hline \multirow[t]{2}{*}{ Спостереження } & \multicolumn{8}{|c|}{ Точки } & \multicolumn{2}{|c|}{ Коефіцієнти } \\
\hline & $\mathrm{T} 1$ & T2 & T3 & $\mathrm{T} 4$ & L1 & L2 & L3 & L4 & $\mathrm{L} 1 / 2$ & $\mathrm{~L} 3 / 4$ \\
\hline 1 & 88,0 & 87 & 86 & 87 & 86 & 92 & 88 & 86 & 0,93 & 0,92 \\
\hline 2 & 61,0 & 59 & 60 & 58 & 59 & 67 & 59 & 61 & 0,88 & 0,97 \\
\hline 3 & 67,0 & 67 & 66 & 66 & 66 & 72 & 68 & 65 & 0,92 & 1,05 \\
\hline 4 & 83,0 & 83 & 81 & 80 & 81 & 87 & 82 & 80 & 0,93 & 1,02 \\
\hline 5 & 91,0 & 87 & 89 & 86 & 87 & 94 & 88 & 89 & 0,92 & 0,99 \\
\hline 6 & 84,0 & 83 & 84 & 83 & 84 & 88 & 84 & 85 & 0,95 & 0,99 \\
\hline 7 & 75,0 & 75 & 73 & 72 & 73 & 79 & 76 & 74 & 0,92 & 1,03 \\
\hline 8 & 67,0 & 66 & 67 & 65 & 66 & 68 & 66 & 67 & 0,97 & 0,98 \\
\hline 9 & 83,0 & 82 & 82 & 81 & 82 & 85 & 83 & 82 & 0,96 & 1,01 \\
\hline 10 & 89,0 & 85 & 88 & 85 & 86 & 93 & 84 & 86 & 0,92 & 0,98 \\
\hline 11 & 92,0 & 89 & 91 & 88 & 89 & 95 & 88 & 89 & 0,94 & 0,99 \\
\hline 12 & 87,0 & 87 & 86 & 85 & 86 & 92 & 86 & 88 & 9,93 & 0,98 \\
\hline 13 & 81,0 & 79 & 79 & 78 & 79 & 86 & 79 & 78 & 0,92 & 1,01 \\
\hline 14 & 85,0 & 85 & 84 & 84 & 84 & 89 & 83 & 82 & 0,94 & 1,01 \\
\hline 15 & 87,0 & 87 & 85 & 85 & 86 & 92 & 85 & 86 & 0,93 & 0,99 \\
\hline Середнє значення & 81,3 & 80,1 & 80,5 & 74,9 & 79,6 & 85,3 & 79,9 & 79,9 & 0,93 & 0,99 \\
\hline
\end{tabular}


Дані щодо показників ехогенності атрофічних рубців наведені в табл. 2.

Середній показник ехогенності інтактної шкіри навколо атрофічних рубців дорівнював 81,3 (у жінок - 84,2, у чоловіків - 82,1). Середні показники ехогенності в ділянках медіального та латерального країв рубця достовірно відрізнялися між собою та дорівнювали 80,1 та 80,5 відповідно (у жінок - 84,3 та 85,1, у чоловіків - 77,3 та 78,1 відповідно). В середній зоні рубця зафіксовані показники ехогенності відносно менші від показників ехогенності інтактної шкіри, вони мали невелику варіабельність, а середнє значення дорівнювало 74,9. Слід зауважити, що у жінок у порівнянні з чоловіками цей показник зафіксовано достовірно більшим - 79,2, але з меншою варіабельністю значень. У чоловіків теж спостерігали невелику варіабельність значень, а середній показник дорівнював 70,6.

Звертала на себе увагу невелика варіабельність показників ехогенності в ділянці між епідермісом та рубцевозміненою тканиною. Ці показники мали майже таку ж варіабельність, що й показники в точках Т2 і Т3, а середнє значення дорівнювало 79,6 (у жінок - 84,3, у чоловіків - 72,6).

Цифрові значення ступеня ехогенності в точці L2 (на межі між рубцевозміненою тканиною та гіподермою) були більшими, відповідно був найвищим і середній показник, який дорівнював 85,3 (у жінок - 90,6, у чоловіків $81,8)$. Отримані нами показники ехогенності у ділянках між медіальним краєм рубця та інтактною дермою і між латеральним краєм рубця та інтактною дермою, були достовірно схожі за своєю варіабельністю з показниками в точках Т2 та Т3, а їх середні значення були однакові і дорівнювали 79,9, що свідчило про однорідність та гомогенність рубцевозмінених тканин в атрофічних рубцях.

Значення індекса L1/2 наближалися до одиниці та дорівнювали в середньому 0,93. Варіабельність значень індекса L3/4 була подібною, вони також наближалися до одиниці та дорівнювали в середньому 0,99.

\section{Обговорення}

Візуально кольорова ехокартина нормотрофічних рубців мінімально відрізнялася від ехокартини дерми інтактної шкіри. За допомогою оптичного та цифрового збільшення візуалізували окремі шари шкіри, які можна було диференціювати, але в 27\% спостережень чіткої межі між дермою та гіподермою не було, хоч відповідні показники ехогенності майже не відрізнялися від показників ехогенності в сосочковому та сітчастому шарах дерми інтактної шкіри.

Серед ехогенних ознак нормотрофічних ПОР слід відзначити збільшення глибини залягання рубцевозміненої тканини у порівнянні з товщиною інтактної дерми в середньому на $8-11 \%$.

Всім пацієнтам з нормотрофічними рубцями проводили також клінічне обстеження із застосуванням авторської стандартизованої системи зовнішньої оцінки стану рубцевозмінених тканин [8], за якою зовнішній стан рубця оцінювали за п'ятьма ознаками: тип, консистенція, колір, чутливість та площа. Результати клінічної та ехологічної верифікації нормотрофічних ПОР збіглися у $98,2 \%$ спостережень.
Значення індекса, отримані шляхом вирахування коефіціентів показників ступеня ехогенності в поверхневих та глибоких шарах середньої зони рубця, мали досить обмежений діапазон, а середнє значення дорівнювало 0,68. Значення індекса, отримані шляхом вирахування коефіцієнтів показників ступеня ехогенності на межі між краями рубцевозміненої тканини та інтактною дермою, мали більшу варіабельність, а середнє значення було достовірно більшим та дорівнювало 1,39.

Відмінністю ехокартини атрофічних рубців $є$ те, що глибина залягання рубцевої тканини менша, ніж товщина інтактної шкіри (мінімальне значення - 0,92 мм, максимальне - 2,14 мм). Власна зона рубця мала середній ступінь ехогенності з досить рівномірним розподілом волокон сполучної тканини.

Серед відмінностей ехокартини слід відмітити також дещо розмиту (верхню) межу дермально-епідермальних зв'язків та більш виражену (нижню) межу, що розділяє рубцевозмінену тканину із гіподермою.

На нашу думку, саме індекси, значення яких наближаються до одиниці, є характерною ознакою ехогенних властивостей атрофічних рубців шкіри та мають застосовуватись в клініці на етапах первинної діагностики.

\section{Висновки}

Якісна та кількісна характеристика варіаційного ряду показників ехогенності свідчить про кореляційний зв'язок між щільністю рубця в різних зонах та ступенем його ехогенності в цих точках, що дає можливість визначити належність рубця до певного типу та спрощує складання алгоритму лікування та профілактики ПОР шкіри на етапі планування.

\section{References}

1. Avetikov DS, Hutnyk AA, Boiko IV, Ivanytska OS, Tsvetkova NV. Biomekhanichne obgruntuvannia odnoosnoi deformatsii shkirno-zhyrovykh klaptiv skronevoi ta vylychnoi dilianok pry vykonanni verkhnoi ritidektomii. Klinichna khirurhiia. 2015;(5):55-7. [In Ukrainian].

2. Loza KhO, Stavytskyi SO, Loza YeO, Voloshyna LI, Avetikov DS. Klinichna kharakterystyka stanu rubtsevo-zminenykh tkanyn shkiry pislia operatsii. Klinichna khirurhiia. 2016;(4):61-3. [In Ukrainian].

3. Skrypnyk VM, Kaidashev IP, Shlykova OA, Avetikov DS. Polimorfizm G28197A $>$ G henu elastynu vyznachaie skhylnist do utvorennia patolohichnykh rubtsiv. Problemy ekolohii i medytsyny. 2012;(16):614. [In Ukrainian].

4. Avetikov DS, Steblovskij DV, Popovich IJu, Lokes KP, Bojko IV. Izuchenie biomehanicheskih svojstv kozhi soscevidnoj oblasti pri vypolnenii kosmeticheskoj oto plastiki. Klinichna hirurgiia. 2015;(8):41-4. [In Russian].

5. Vu VK, Avetikov DS, Shlykova OA. Vozniknovenie odontogennoj flegmony associirovannoj s polimorfnym variantom 896A/G gena TLR4, no ne 2258G/A gena TLR2. Klinichna hirurgiia. 2014;(10):54-6. [In Russian].

6. Avetikov D, Loza K, Starchenko I, Loza EO, Marushchak MI. Experimental-morphological substantiation of expediency to use the skin glue «Dermabond» for postoperative wound closure. 2015;(7-8):244-5.

7. Neligan P. Plastic Surgery. Volume 2 Aesthetic. Neligan. USA: Elsevier; $2013.555 \mathrm{p}$.

8. Lakin Gregory. Plastic Surgery Review. Gregory Lakin. Germany: Thieme; 2015. 235 p. 